\title{
Behavioral Skills Outcome of Technical Education Students Engaged in Cooperative Learning
}

\author{
Oguguo Uchechukwu Chikodili \\ Department of Industrial and Technical Education \\ University of Nigeria, Nsukka Nigeria
}

\begin{abstract}
This study determined the behavioral skill outcome of technical education students engaged in cooperative learning. Specifically, the study sought to identify the effects of cooperative learning on technical education student's communication skill, problemsolving skill and critical thinking skill. There were three research questions posed, and the analysis was driven by three null hypotheses tested at $(\mathbf{P}<.05)$ level of significance. It has adopted a quasi-experimental design for the study and intact classes were assigned to treatment groups. The study's population was 41 students of Technical Education (TE), consisting of 41 year 3 students of Industrial Technical Education at the University of Nigeria, Nsukka, which was the treatment group allocated to the teaching method of cooperative learning. The instrument used for data collection was the self-assessment inventory of communication skills (CSSAI), the inventory of problem-solving skills (PSSI), and the California Critical Thinking Skills Test (CCTST). Three technical education experts had subjected the instruments to face and content validation. Mean and standard deviation were used to answer the study questions while Paired-sample t-test was used to answer the null hypotheses. Findings showed, among others, that there is a significant difference between the pretest and posttest mean scores taught by Automobile Lighting System students who use cooperative learning in terms of behavioral skill outcome. Among others, it was proposed that technical education teachers be encouraged to use the cooperative learning method in teaching automotive lightening program.
\end{abstract}

Keywords:- Behavioral skills; cooperative learning; Technical education.

\section{INTRODUCTION}

The need for craftsmen and women in Nigeria's economic and social sectors has resulted in the introduction of the Technical Vocational Education and Training (TVET) programs provided by the technical colleges and institutions in Nigeria. There's more emphasis on industrial and technological development in contemporary Nigeria, which is why students are encouraged to study subjects related to Science Technology Engineering and Mathematics (STEM) in technical colleges and institutions. Technical education (TE) courses such as automobiles, Building, Electrical / Electronics, Metalwork and Woodwork Technology will not be effectively taught on the basis of pure theoretical knowledge without the

\author{
Ogbuanya. Theresa Chinyere \\ Department of Industrial and Technical Education, \\ University of Nigeria, Nsukka Nigeria
}

implementation of other teaching techniques. This is because instructional approaches are structured to help educators become autonomous and strategic learners (Mustapha, 2018).

\section{$>$ Literature Background}

In time past, teachers have focused on "Chalk-Talk technique," a teacher-centered strategy where words are used to communicate and convey concepts or reality in teaching and learning processes (Onasanya, Adegbija, Olumorin \& Daramola, 2009). In order to reinforce this point, Osakinle, Onijigin and Falana (2010) argued that this strategy is being pursued in all areas where practical work is needed. Despite the existence of multiple teaching strategies proposed to cope with the recent change in the various school curriculum systems, evidence has continued to suggest that most teachers tend to follow the chalk-talk teaching techniques (Woldab, 2013). Such approaches also cause disappointment and learning problems that contribute to low academic performance for the majority of students (Bala, 2006). The report of the NABTEB May / June Chief Examiner (2014) indicated that the deficiencies in the current training technique were partly due to the poor performance of the NTC examination students in recent years. Literature work has shown that researchbased learning techniques can be used to improve the academic achievement of students (Saka, Owodunni \& Babatunde, 2016). The individual's behavior has had to be positively influenced for learning to be achieved. In technical education, the behavior of learners is also expected to be modified to reflect key components such as knowledge and attitude about skills. Uwaifo (2010) states that technical education is the training associated to technically focused workers as the initiators, facilitators and implementers of technological growth in a nation by adequately educating its people on the need for technological literacy, leading to self-confidence and sustainability. Uwaifo also observed that technical education has a direct impact on the country's development, more than any other profession.

Technical education is practically oriented education and therefore requires special attention in its content and approach. As a result, technical education can act as advocates of change not only for technical systems, but also for many other changes in society. Technical education's realistic nature makes it unique in content and approach, and requires special attention and care. Different educational approaches are used to attain the objective of technical education, one of which is cooperative learning. 
An important principle in education is a cooperative approach to learning. According to Johnson and Johnson (2013), co-operative learning is the educational use of small groups such that students work together to improve their own and shared learning. In other words, cooperative learning is a set of instructional learning methods aimed at encouraging students to work together on academic tasks, thereby maximizing learning for themselves and for each other. Similarly, Slavin (2011) defined cooperative learning as instructional methods in which teachers organize students into small groups and then cooperate to help each other learn academic content. Yusnani (2018) also expressed the view that cooperative learning is a study approach aimed at managing classroom activities in academic and social learning experiences. The researcher also stressed that cooperative learning not only arranges students into groups, but has proved to be a structuring of positive interdependence. Students have many differences, in gender, race or learning styles. Yusnani further believed that cooperative learning dissolves all these diversities into interdependence of cognitive, behavioral, and social. Cognitive interdependence is a state of mind characterized in relation by pluralism and collective self-representations. Behavioral interdependence refers to the mutual impact people have on each other as they intertwine their lives and their daily activities (Yusnani, 2018). What one person does can and will influence what the other person wants to do. Behavioral interdependence strengthens the relationship between individuals within the same group. Social interdependence in cooperative learning brings in positive interdependence, individual responsibility, the effective use of social skills and group processing for promotional interaction. Such fundamental elements, namely positive interdependence, face-to - face engagement, individual accountability, interpersonal \& social skills, and group processing, must be present in the co-operative classroom to involve students in learning (Johnson \& Johnson, 2008). If students are grouped into groups without a positive interdependence, learning conditions are not cooperative (Johnson \& Johnson, 2009). Positive interdependence means cooperative learning situations requiring students to work together as a cohesive group to reach shared learning goals (Yager, 2000; Jensen, Moore \& Hatch, 2002). Face-to - Face Promotive Interaction is the second dimension of cooperative learning. Positive interdependence results in reciprocal interaction between individuals that fosters the success and achievement of each member of the community. Promoting engagement occurs as individuals support and promote each other's efforts to attain the group's goals. Students are required to interact verbally with each other regarding learning tasks in cooperative learning groups (Johnson \& Johnson, 2008). Individual accountability is considered to be the degree to which the achievement of the group depends on the individual learning of all members of the group. If there is no individual accountability, one or two members of the group may do all the work while others do nothing. Responsibility forces increase when group accountability and individual accountability exist within the group (Johnson \& Johnson, 2008). Fourth key element of cooperative learning is interpersonal and social skills. In fact, if socially unskilled students are grouped into a single community, students cannot function effectively (Johnson \& Johnson, 2006).

For this reason, social and interpersonal skills, such as listening carefully, questioning cooperatively and communicating politely, need to be taught to help students successfully cooperate within the community (Killen, 2007). Group processing is defined as reflecting on a group session to help students describe what member actions were helpful and unhelpful, and to decide what actions to continue or change (Johnson et al., 1994). Group processing helps improve members' effectiveness in contributing to the shared efforts to achieve the group 's objectives through a study of the learning process (Yamarik, 2007). In other words, the purpose of group processing is to explain and enhance the members' effectiveness in contributing to collective efforts to achieve the group 's objectives. Cooperative learning is an alternative learning method other than a teacher-oriented method, because at present, students rarely build face-to face interactions between others due to their addiction to gadgets. Thus, this condition causes them to be neglected. In order to create a friendlier atmosphere for learning, a teaching method must be in place that can improve social interaction and in which cooperative learning is the way forward. There are three types of cooperative learning groups, namely formal cooperative learning, informal coop learning, and core co-operative groups (Johnson, Johnson, \& Holubec 2008). Formal co-operative learning involves students working together, over a period of several weeks, to achieve shared learning goals and jointly perform specific tasks and activities (such as problemsolving, completing a curriculum project, writing a report, conducting an experiment, or engaging in a dialog on assigning text material). Any criteria for courses or assignments may be arranged in a cooperative way. Informal cooperative learning consists of making students work together to accomplish a common learning objective of a temporary, ad hoc group that can last from a few minutes to a full class period. Cooperative grassroots groups are long-term, heterogeneous, stable-member cooperative learning groups whose primary roles are to provide support, encouragement, and assistance in fostering academic progress and sound cognitive and social growth, as well as to keep each other accountable for learning efforts. Cooperative learning focuses positively on academic achievement. Cooperative learning can be juxtaposed with competitive learning (students compete against each other to achieve an academic objective such as "A" grade that only one or a few students can attain) and individualistic learning (students compete independently to achieve learning goals that are unrelated to those of the others). In co-operative and individualistic learning, student actions are evaluated on a criterion basis, whereas students are evaluated in competitive learning on a standard-referenced basis (Johnson \& Johnson, 2013). In cooperative situations, individuals seek outcomes which benefit both themselves and other members of the community. Such situations ensure and foster behavioral competencies. 
Behavioral skills are essential to any learning approach. Behavioral skills refer to an individual 's analytical capacity regarding the characteristics of the circumstances that the individual may encounter (Step4SFC, 2019, para. 1). This ability can be organizational when the individual reacts in relation to the quality of the work, example, prioritization, anticipation and control; social or interpersonal when the individual reacts to others and establishes relationships, examples include, but are not limited to, negotiating, discussing, cooperating, or emotional and psychological (when the individual works with others and the individual's own limitations include, for example, adaptation, training. In the same vantage point. Doyle (2019) claimed that behavioral skills frequently come under the general heading of good character, friendliness, maturity, or common sense, and many people assume that they are of course good or intelligent. In addition, the researcher says these are skills which need to be learned and exercised. The good news is that it is entirely possible to develop such behavioral skills at any time. Much of these competencies in actions are of a social nature. You wonder how well you can get along with others, like your manager, subordinates, customers and consumers. Given the behavioral skills problems of cooperative learners in technical education, the researcher wishes to investigate the effects of cooperative learning on the technical education student's behavioral skills in Automobile Lighting System.

\section{$>$ Theoretical framework}

Several researchers have established theories of cooperative learning. In this analysis, the writer concentrates on the theories of Piaget and Vygotsky. Research by Jean Piaget (1959) demonstrated the benefits of cognitive conflicts among students, which expose student prejudices and contribute to higher-quality understandings. Studies by Vygotsky (1978, p.90) stressed the benefits of working with a more professional mentor as what one student does in tandem with another could be translated into his performance. Research on cooperative learning methods was conducted from two key theoretical, developmental, and motivational perspectives. The developmental perspective is based on the Piagetian and Vygotskian theories that task-focused interaction between students improves learning by generating cognitive conflicts and exposing students to higher-quality thinking. In comparison, cooperative learning motivational theories argue that rewarding communities focused on the individual success of all community members build peer expectations and penalties that promote achievementrelated activities and positive peer support. In the developmental view, rewards are counterproductive for community learning activities, while in the motivationalist view they are essential for improving the learning outcomes. The effects of cooperative learning on student performance from a developmental perspective will be primarily attributed to the use of cooperative tasks. Under this view, the ability for students to debate, argue, and express their own perspectives, and listen to each other's perspectives, is the central element of student achievement cooperative learning.
The main theory underpinning cooperative learning refers to Vygotsky's advanced social constructivism, which considered the roles of culture and society, language, and interaction to be important in understanding how human beings learn. In his study with children, Vygotsky assumed that knowledge is cultural; he adopted a socio-cultural approach. This approach can be defined in brief as being cooperative and cultural. Vygotsky claimed that the creation of individuals is a function of community, including their emotions, languages, and thinking processes. Thus these abilities are formed by social experiences with others, they reflect the mutual experience of a specific community. Vygotsky studied children's growth from their environment and, through their interaction with others, found that what is given and what happens in the social environment (e.g., dialogues, actions and activities) is helping children learn, develop and grow. Social interaction is an important way in Vygotsky's social constructivism in which children gain accessible information in their society without having to recreate it by them. Parents, parents, careers, teachers and peers play critical roles in children's learning appropriation process. Teachers and adults are giving students direction and instructions, comments and feedback. Students don't passively receive these because they also communicate with teachers, interactively conveying their problems or answers to them. Kids often use discussions in performing lessons, tasks and conflicts with their peers. We share ideas and obtain information in this way, and thus create awareness and knowledge creation. This process of learning is considered important because knowledge is developed through history itself and should be used through appropriation in a social context. Learning is achieved through the development process; learners should indeed be active participants in the learning process. Learning activity is important; it is also a key concept in socio-cultural theories that explains the importance of doing things. Through meaningful activities, learners interact with peers and more knowledgeable people. Through interaction, students develop dialogs within the activity structure, resulting in learning and development. Technical education students engage in this form of interactive learning with peers thereby developing basic behavioral skills.

This does not allow students to express themselves, ask questions and direct their learning as teacher-centered education has full control over the classroom and its activities. If the teacher succeeds in the process of teaching and learning, the chances of the student losing sight of their goals are greater than that of developing their knowledge. Brophy (as quoted in Mpho, 2018) confirms this by suggesting that the primary emphasis of a behavioral model for classroom management is the use of strategies that bring the behavior of students under stimulation regulation while teacher-centered instruction is performed, the classroom remains structured and the students are quiet as long as the teacher is maintains complete power and thus denies them the ability to engage fully in their learning. When the teacher becomes dominant in the cycle of teaching and learning, teaching is boring for 
the students, causing them to worry about their minds and can forget important information. These behavioral approaches to classroom management have been interpreted as consistent with a traditional teaching approach in which students are not permitted to express themselves and direct their learning, which hampers the outcome of positive behavioral skills (Tabulawa, 2006). Ashworth (as cited in Mpho, 2018) states that despite the negative outcomes of teacher-centric learning approaches that affect the behavioral skills outcome of technical education students, technical education institution still has to engage more in teacher-centric learning than a studentcentric learning approach that plays a vital role in decisionmaking processes which is a behavioral skill acquire in student-centered learning approach like cooperative learning.

\section{Research questions and hypotheses}

This study addresses the following three research question and their corresponding hypotheses:

- What is the effect of cooperative learning on technical education student's communication skill? We hypothesized that significant difference does not exist between the pre-test and post-test mean score of students taught automobile lighting system using cooperative learning with regards to communication skills.

- What is the effect of cooperative learning on technical education students problem-solving skill? We hypothesized that significant difference does not exist between the pre-test and post-test mean score of students taught automobile lighting system using cooperative learning with regards to problem solving skills.

- What is the effect of cooperative learning on technical education students critical thinking skill? We hypothesized that significant difference does not exist between the pre-test and post-test mean score of students taught automobile lighting system using cooperative learning with regards to critical thinking skills.

\section{METHODS}

\section{$>$ Participants}

The study consisted of 41-year III Technical education students of Industrial Technical Education (Automobile Technology) in University of Nigeria, Nsukka which constituted the treatment group assigned to cooperative learning method of teaching.

\section{$>$ Measures}

The instrument used for data collection were the Communication skills self-assessment inventory (CSSAI), problem-solving skills inventory (PSSI) and the California Critical Thinking Skills Test (CCTST). Communication skills self-assessment inventory (CSSAI) was developed by HTC Consulting. (N.D) which consisted of 20 items. (CSSAI) items were tested on 5-point Likert scale ( strongly Disagree $=1$ to $5=$ Strongly agree). Problemsolving skills inventory (PSSI) was developed by Heppner $\&$ Petersen (1982) which consisted of 35 items. (PSSI) items were tested on 5-point Likert scale (Very Dissatisfied $=1$ to $5=$ Very Satisfied). The California Critical Thinking Skills Test (CCTST) was developed by Facione \& Facione (1994) which consisted of 34 items. (CCTST) items were tested on 5-point Likert scale (Not like me at all $=1$ to $5=$ Exactly like me).

\section{$>$ Procedure}

A pre-test was administered to the students' in their intact class which lasted for 45 minutes. The Pre-test was used to establish the level of behavioral skills which the students have prior to treatment. Thereafter, the students were subjected to 6 weeks of formal instructions using cooperative learning method to teach the students automobile lightening system. At the end of the formal instructions a posttest was administer. The instruments administered as pre-test was also given as post-test. The scores obtained from the post-test exercise provided posttreatment data for the study.

\section{Analyses}

Data collected were analyzed using mean and standard deviation for answering the research questions while paired sample t-test was used in testing the null hypotheses at 0.05 level of significance.

\section{RESULTS}

Research Question 1

What is the effect of cooperative learning on technical education student's communication skill?

\begin{tabular}{|c|c|c|c|}
\hline Experimental Group & N & Mean & SD \\
\hline PRETEST & 41 & 17.29 & 2.32 \\
\hline POSTTEST & 41 & 24.04 & 2.65 \\
\hline Mean Difference & & 6.75 & \\
\hline
\end{tabular}

Table 1:- Pretest and Posttest Mean score of cooperative learning on technical education student's communication skill 
Result in Table 1 shows the pretest and posttest mean scores of Cooperative Learning Method (CLM) of technical education students communication skill which were 17.29 and 24.04 respectively. The result shows that posttest mean score is greater that pretest mean score which implies that cooperative learning instructional strategy is effective in improving technical education student communication skill on automobile lightening system.

\section{Research Question 2}

What is the effect of cooperative learning on technical education students problem-solving skill?

\begin{tabular}{|c|c|c|c|}
\hline Experimental Group & N & Mean & SD \\
\hline PRETEST & 41 & 14.12 & 1.00 \\
\hline POSTTEST & 41 & 23.63 & 1.77 \\
\hline Mean Difference & & 9.51 & \\
\hline
\end{tabular}

Table 2:- Pretest and Posttest Mean score of cooperative learning on technical education student's Problem-Solving skill

Tables 2 Result in Table 1 shows the pretest and posttest mean scores of Cooperative Learning Method (CLM) of technical education students problem solving skill which were 14.12 and 23.63 respectively. The result shows that posttest mean score is greater that pretest mean score which implies that cooperative learning instructional strategy is effective in improving technical education student problem solving skill on automobile lightening system.

\section{$>\quad$ Research Question 3}

What is the effect of cooperative learning on technical education students critical thinking skill?

\begin{tabular}{|c|c|c|c|}
\hline Experimental Group & N & Mean & SD \\
\hline PRETEST & 41 & 14.68 & 1.84 \\
\hline POSTTEST & 41 & 23.73 & 1.73 \\
\hline Mean Difference & & 9.05 & \\
\hline
\end{tabular}

Table 3:- Pretest and Posttest Mean score of cooperative learning on technical education student's Critical Thinking skill

Result in Table 3 shows the pretest and posttest mean scores of Cooperative Learning Method (CLM) of technical education students critical thinking skill which were 14.68 and 23.73 respectively. The result shows that posttest mean score is greater that pretest mean score which implies that cooperative learning instructional strategy is effective in improving technical education student critical thinking skill on automobile lightening system

Hypothesis 1: Significant difference does not exist between the pre-test and post-test mean score of students taught automobile lighting system using cooperative learning with regards to communication skills.

\begin{tabular}{|c|c|c|c|c|c|c|c|}
\hline TEST & N & Mean & SD & t-value & df & Sig. & Decision \\
\cline { 1 - 2 } & 41 & 17.29 & 1.96 & -16.42 & 40 & 0.00 & $\mathrm{~S}$ \\
\hline POSTTEST & 41 & 24.04 & 1.82 & & & \\
\hline
\end{tabular}

Note: significant at 0.05 2-tail level of significance

Table 4:- Paired- Samples T-Test of difference between the pre-test and post-test mean score of students taught automobile lighting system using cooperative learning with regards to communication skills.

Data presented in Table 4 showed the Paired- Samples T-Test of difference between the pre-test and post-test mean score of students taught automobile lighting system using cooperative learning with regards to communication skills. The result shows a significant level of 0.00 which is less than 0.05 level of significant as a decision bench mark. This signifies that the null hypotheses of no significant difference between the pre-test and post-test mean score of students taught automobile lighting system using cooperative learning with regards to communication skills is therefore rejected. Inference drawn is that significant difference exist between the pre-test and post-test mean score of students taught automobile lighting system using cooperative learning with regards to communication skills.

Hypothesis 2: Significant difference does not exist between pre-test and post-test mean score of students taught automobile lighting system using cooperative learning with regards to problem-solving skills. 
ISSN No:-2456-2165

\begin{tabular}{|c|c|c|c|c|c|c|c|}
\hline TEST & N & Mean & SD & t-value & df & Sig. & Decision \\
\cline { 1 - 3 } PRETEST & 41 & 14.12 & 1.00 & -31.85 & 40 & 0.00 & S \\
\cline { 1 - 4 } POSTTEST & 41 & 23.63 & 1.77 & & & & \\
\hline
\end{tabular}

Note: significant at 0.05 2-tail level of significance

Table 5:- Paired- Samples T-Test of difference between the pre-test and post-test mean score of students taught automobile lighting system using cooperative learning with regards to Problem Solving Skill.

Data presented in Table 5 showed the Paired- Samples T-Test of difference between the pre-test and post-test mean score of students taught automobile lighting system using cooperative learning with regards to problem solving skill. The result shows a significant level of 0.00 which is less than 0.05 level of significant as a decision bench mark. This signifies that the null hypotheses of no significant difference between the pre-test and post-test mean score of students taught automobile lighting system using cooperative learning with regards to problem solving skill is therefore rejected. Inference drawn is that significant difference exist between the pre-test and post-test mean score of students taught automobile lighting system using cooperative learning with regards to problem solving skill.

Hypothesis 3: Significant difference does not exist between the pre-test and post-test mean score of students taught automobile lighting system using cooperative learning with regards to critical thinking skills

\begin{tabular}{|c|c|c|c|c|c|c|c|}
\hline TEST & N & Mean & SD & t-value & df & Sig. & Decision \\
\cline { 1 - 3 } PRETEST & 41 & 14.68 & 1.84 & -25.91 & 40 & 0.00 & S \\
\cline { 1 - 4 } POSTTEST & 41 & 23.73 & 1.73 & & & & \\
\hline
\end{tabular}

Note: significant at 0.05 2-tail level of significance

Table 6:- Paired- Samples T-Test of difference between the pre-test and post-test mean score of students taught automobile lighting system using cooperative learning with regards to Critical Thinking Skill.

Data presented in Table 6 showed the PairedSamples T-Test of difference between the pre-test and posttest mean score of students taught automobile lighting system using cooperative learning with regards to critical thinking skills. The result shows a significant level of 0.00 which is less than 0.05 level of significant as a decision bench mark. This signifies that the null hypotheses of no significant difference between the pre-test and post-test mean score of students taught automobile lighting system using cooperative learning with regards to critical thinking skills is therefore rejected. Inference drawn is that significant difference exist between the pre-test and posttest mean score of students taught automobile lighting system using cooperative learning with regards to Critical Thinking skill.

\section{DISCUSSION}

The findings revealed that there was significant difference in the behavioral skill outcome of technical education student due to cooperative learning. The effect of CLM on technical education student's behavioral skill outcome on the posttest mean score is higher than the effect of pretest mean score. This implies that pretest had a low mean score compared to posttest in the experimental treatment. The result of the study agrees with Quines (2017) on effectiveness of cooperative learning approach in developing critical thinking skill of secondary students. According to the result, cooperative learning is an effective alternative to the conventional method of developing critical thinking skills. The elements of this method help to develop critical thinking skills and social skills of learners. Findings from the study also revealed that cooperative learning method is significantly related to critical thinking. Similarly, the findings of this study also agreed with the findings of Baghcheghi, Koohestani and Rezaei (2011) who compare the effect of traditional learning and cooperative learning methods on nursing students' communication skill with patients where the authors found that cooperative learning is an effective method for improving and increasing communication skills of nursing students especially in interactive skills. In same vein, findings from this study is in collaboration with Ajaja and Eravwoke (2010) who found out that cooperative learning method improves student's achievement than the traditional methods.

\section{LIMITATION AND FUTURE RESEARCH}

Although this study is quasi- experimental study with one- group design which does not include a no- treatment control group or a business-as-usual comparison group is still prone to many threats to internal validity, including those associated with observing the same participant over time. Based on the findings of the study, the following recommendations were made:

$>$ Teacher training institutions should structure and restructure the special methodology course to include synergy between the conventional teaching method and cooperative learning method in the automobile lighting system. 
- Educational administrators should monitor schools regularly to ensure that effective methods of instruction like cooperative learning are harnessed to enhance student's behavioral skill.

$>$ There should be policy framework development that will guarantee the judicious use of cooperative learning method for instructional delivery in technical education institutions.

\section{CONCLUSION}

The result of these study revealed that cooperative learning enhances the behavioral skill outcome of technical education students taught automobile lightening system. It is hoped that teachers should be encourage to employed more of cooperative learning when teaching automobile lightening system.

\section{REFERENCES}

[1]. Ajaja, P.O. \& Eravwoke, O.U. (2010). effect of cooperative learning strategy on junior secondary school students achievement in integrated science. Electronic journal of science Education 14(8) 3435

[2]. Baghcheghi, N., Koohestani, H. R., \& Rezaei, K. (2011). A comparison of the cooperative learning and traditional learning methods in theory classes on nursing students' communication skill with patients at clinical settings. Nurse education today, 31(8), 877-882.

[3]. Bala, B. (2006). Quantitative method for computing Student (An active learning approach). London: ADP Publication.

[4]. Doyle A. (2019). Important of behavioral skills that employers value. Retrieved from https://www.thebalancecareers.com/behavioralskills-list-2063733

[5]. Edina, MN: Interaction Book Company.

[6]. Facione, P. A., \& Facione, N. (1994). The California Critical Thinking Skills Test: CCTST: Test Manual. California Academic Press.

[7]. Heppner, P. P., \& Petersen, C. H. (1982). The development and implications of a personal problem-solving inventory. Journal of counseling psychology, 29(1), 66.

[8]. HTC Consulting. (N.D). Communication skills selfassessment inventory. Retrieved from 04/11/2019 from http://bit.ly/13X3plM

[9]. Johnson, D. W., \& Johnson, R. T. (2010). The impact of cooperative, competitive, and individualistic learning environments on academic achievement. In J. Hattie \& E. Anderman (Eds.). (in press). International handbook of student achievement.

[10]. Johnson, D. W., Johnson, R., \& Holubec, E. (2008). Cooperation in the classroom ( $7^{\text {th }}$ ed.).

[11]. Mpho, O. M. (2018). Teacher centered dominated approaches: Their implications for todays inclusive classrooms. International Journal of Psychology and Counselling, 10(2), 11-21.
[12]. Mustapha, A. (2018). Effects of e-content on students' achievement, interest and retention in learning automobile lighting system in technical colleges in Niger State. Unpublished M.Tech thesis Federal University of Technology Minna

[13]. Onasanya, S. A., Adegbija, M. V., Olumorin, C. O., \& Daramola, F. O. (2009), "Education reform and Assessment of Teachers Competence in Instructional Media Technology Use In: Education reforms in Nigeria- Past, Present and Future", Lawal A.R.(Eds) Lagos: Stirling Horden Publisher.

[14]. Osakinle, E. O., Onijigin, E. O., \& Falana, B. A. (2010). Teaching Methods and Learners' Environment in a Nigerian University. African Journal of Basic \& Applied Sciences, 2 (1-2), 7-10.

[15]. Piaget, J. (1959). The Language and Thought of The Child (Vol. 5). Chicago: Psychology Press

[16]. Quines, E. (2017). Effectiveness of cooperative learning approach in developing critical thinking skills of secondary students. In Empowering 21st century learners through holistic and enterprising learning (pp. 115-123). Springer, Singapore.

[17]. Saka, A. I., Owodunni, A. S. \& Babatunde W. H. (2016). Comparative Effects of Structured and Guided Inquiry Instructional Techniques on Students' Academic Achievement in Basic Electricity in Kwara State Technical Colleges. Unpublished Ph.D thesis University of Ilorin.

[18]. Slavin, R. E. (2011). Instruction Based on Cooperative Learning. In R. E. Mayer \& P. A. Alexander (Eds.), Handbook of Research on Learning and Instruction (pp. 344-360). New York: Taylor \& Francis.

[19]. Step4-SFC (2019). Behavioral skills, an asset for sustainable development. Retrieved from https://step4-sfc.eu/OPC-SFC-what-is-it

[20]. Uwaifo, V. O. (2010). Technical Education and its Challenges in Nigeria in the 21st Century. International NGO Journal,5(2), 040044.

[21]. Vygotsky, L. S. (1978). Mind in society: The development of higher psychological processes. Cambridge, MA: Harvard University Press

[22]. Woldab, A. E. (2013). Constructivist Didactics in Teaching Economics: A Shift in Paradigm to be Exemplary Teacher. Academic Journal of Interdisciplinary Studies 2 (1), 197-203.

[23]. Yusnani, (2018), "Theoretical Perspectives on Cooperative Learning" in the 1st Annual International Conference on Language and Literature, KnE Social Sciences, pages 976-986. DOI 10.18502/kss.v3i4.2005 